\title{
RAINFALL RUNOFF MODELING FOR CATCHMENTS HAVING LOW QUALITY SCARCE DATA
}

\author{
Ghumman A. R. ', Yousry Ghazaw ${ }^{2}$ and M.S. Abulohom ${ }^{1}$ \\ 1 University of Engineering and Technology Taxila, Pakistan \\ 2 Engineering College, Qassim University, Saudi Arabia \\ On leave from: Faculty of Engineering, Alexandria University, Egypt
}

\begin{abstract}
Monthly runoff from a catchment is required for water resources engineering and management. This paper deals with runoff modeling from catchments which have scarce data of low quality. Two models namely mathematical conceptual model and Multivariate AutoRegressive - Moving Average model (MARMA) were developed and applied to two catchments (Brandu River and Khost River catchments) in Pakistan. The precipitation and meteorological data used were collected from Meteorological Department Baluchistan and North West Frontier Province, Pakistan. The results of mathematical conceptual model and multivariate autoregressive - moving average model were compared with each other. It was observed that multivariate autoregressive moving average model could not provide the satisfactory results due to presence of high nonlinearity in the Rainfall-Runoff (R-R) processes of these watersheds. The performance of the conceptual model was acceptable.

Keywords: Brandu River; Khost River; Autoregressive, Mathematical models; Low quality; Runoff.
\end{abstract}

Keywords: Brandu River, Khost River, Autoregressive, Mathematical models, Low quality, Runoff.

\section{INTRODUCTION}

Water resources planning and management play an important role in lifting up the economy of many countries world-wide. Water supply schemes, irrigated agriculture and watershed management need forecasts of runoff from rainfall. Rainfall-runoff (R-R) modeling is a challenging task for engineers and researchers in this field of specialization. It is difficult because many variables are involved in rainfall runoff process. The variables are interconnected in a complex manner. Several kinds of rainfall-runoff models have been applied in past (Bhadra et al 2010). Distributed physically based models produce relatively accurate results but these models need a lot of data. Most of the developing countries do not have such data (Masood et al 2010). Time series stochastic models are also found in literature (Tingsanchali and Gautam, 2000, Bahremand A and Smedt, 2010 ). These models are also complicated and are subject to the experience of the modeler. Neural Network models are another alternative but it is difficult for neural network models to pick up all the nonlinearity of rainfall runoff process (Shamseldin, 1997).

Conceptual mathematical models can be simplified and applied to the situation where data is scarce and of low quality. There are 
two types of conceptual mathematical rainfallrunoff models namely distributed and lumped models. The distributed models take care of most of the features of catchment and require huge data for determination of parameters of the models. However the lumped models consider the catchment as homogenous and take it a sole unit like the models developed by Abulohom et al. (2001), Perrin et al. (2003) and Boughton and Chiew (2007) for example. Such models require limited amounts of input data for identification of model parameters. A simple lumped mathematical model was developed in this paper and applied to catchments of two rivers (River Brandu and River Khost) in Balochistan and North West Frontier Province of Pakistan. Multivariate AutoRegressive and Moving Average model (MARMA) was also developed for these watersheds for comparison purpose.

\section{DESCRIPTION OF THE STUDY AREA}

Both of the watersheds used in this study have been studied by Abulohom et al. (2001). They have described the two catchments in detail. Some of the aspects of this description are reproduced here for ease of the readers. The rough idea of locations of watersheds of Brandu River and Khost River can be taken from Fig. 1. Further details are given below:

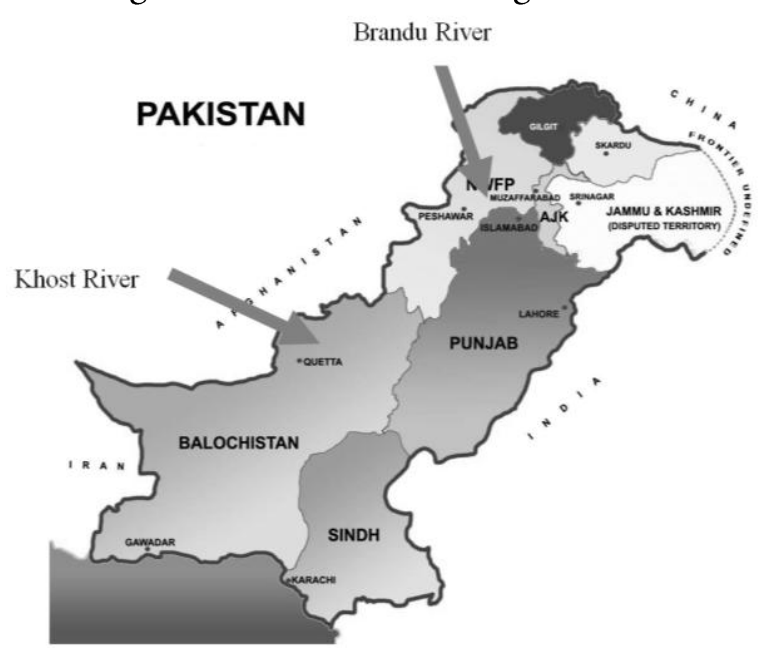

Fig. 1. The approximate locations of two studied watersheds in Pakistan.

\subsection{BRANDU RIVER WATERSHED}

The catchment of Brandu River is located in the Swat District of North West Frontier Province of Pakistan (34' 30' 44" N, $72^{\circ} 29^{\prime}$ $\left.10^{\prime \prime} \mathrm{E}\right)$. The elevation of the catchment is between $732 \mathrm{~m}$ to $2134 \mathrm{~m}$ above mean sea level. The catchment area is about $598 \mathrm{~km} 2$. The slopes are mild. The fine grained clay and silt are dominant parts of soil. Some part of the catchment consists of rough and broken lands. Stony mountainous lands also exist. There is cultivated area due which a good vegetation cover is available. Groundwater depths are shallow in some parts of the catchment. The climate of the Brandu River catchment is sub-tropical, sub-humid continental, and has a maximum of annual precipitation of $1025.72 \mathrm{~mm}$ in the past. The monsoon from July to September is the main cause of precipitation in the area. In 2010 it has a record flood which damaged several lives and property and crops of millions of US dollars. The rainfall rate is low in other seasons of the year. There are occasionally occurring low floods due to single events of rainfall. The contribution from Baseflow and groundwater is also observed to the Brandu River due to which some high flows are recorded against low rainfalls (Soil Survey of Pakistan, 1975).

\subsection{KHOST RIVER WATERSHED}

The catchment of Khost River lie in the Province of Balochistan, Pakistan.(30 ${ }^{\circ} 12^{\prime}$ $56^{\prime \prime} \mathrm{N}, 67^{\circ} 35^{\prime} 17^{\prime \prime} \mathrm{E}$ ). The elevation of the catchment is approximately $1500 \mathrm{~m}$ above mean sea level. The catchment area is about $1320 \mathrm{~km} 2$. The climate of the Khost River catchment is arid. The mean annual precipitation is only $305 \mathrm{~mm}$. Most of rains occur during winter and spring seasons. There is some agricultural activity due to which the vegetation cover is found in some of the area. The geology of the area has variety of land 
forms. It includes planes of mild slope, mountains and small hills. The type of rocks is calcareous.

\subsection{MATERIALS AND METHODS}

\subsubsection{Description of Mathematical Model}

The model is based on the equation of continuity. Its general and simplest form is given by the following equation:

$R=P-L$

Where $\mathrm{R}$ denotes total runoff, $\mathrm{P}$ represents precipitation and $\mathrm{L}$ is for losses. The units of the quantities in equation (1) are mainly in $\mathrm{mm}$.

Runoff from rainfall was modeled by regression analysis (Vandewiele et al 1992). Therefore parameters of the model are considered as catch all parameters representing in-directly the characteristics of the basin under study i.e. soil type, vegetation cover, and geology.

Runoff

The total runoff $\mathrm{R}$ may have two components namely the direct runoff and the base-flow. Direct runoff can be given as (Vandewiele et al 1992)

$(D R)_{i}=A_{1}\left(S M_{i-1}\right)^{B 1}\left(P_{e}\right)_{i}$

Where (DR)i is direct runoff in month $i, A 1$ and $\mathrm{B} 1$ are the model parameters. SMi-1 is initial soil moisture contents at the beginning of month $i$, and $(\mathrm{Pe}) \mathrm{i}$ is the effective precipitation expressed

$\left(P_{e}\right)_{i}=P_{i}-\left(E_{a c t}\right)_{i}\left\{1-\exp \left[-P_{i} /\left(E_{a c t}\right)_{i}\right]\right\}$

Where Pi is the precipitation in month $\mathrm{i}$ and (Eact) $\mathrm{i}$ is the actual evapo-transpiration in month i.

The base-flow can be given as (Vandewiele et al ,1992):

$(B F)_{i}=A_{2}\left(S M_{i-1}\right)^{B 2}$

Where $(\mathrm{BF}) \mathrm{i}$ is groundwater component of runoff in month $\mathrm{i}$.
The model parameter A1, A2, B1, and B2 described above have indirect physical meaning. These parameters were determined by optimization.

One thing worth mentioning here is that the soil moisture at the end of the current month was considered as the initial value for the next month of simulation.

The monthly actual evapotranspiration (Eact)i was estimated by the available water during month $\mathrm{i}$ and mean monthly potential evapotranspiration (Epan)i. (Epan)i was measured by pan (further details can be seen from Vandewiele \& Win 1998).

Having estimated the runoff from the catchment the Muskingum method was used for routing the runoff to get the flow in the river at some point of interest as explained below (Ponce, 1989).

$(Q R)_{i+1}=C_{0} R_{i+1}+C_{1} R_{i}+C_{2}(Q R)_{i}$

Where $(\mathrm{QR}) \mathrm{i}+1=$ River flow at the point of interest downstream of catchment at end of month $\mathrm{i}+1,(\mathrm{QR}) \mathrm{i}=$ previous runoff at the watershed outlet at end of month $i$, at the same point $\mathrm{Ri}+1=$ estimated runoff at end of month $\mathrm{i}+1$ at watershed outlet, and $\mathrm{Ri}=$ previous estimated runoff at end of month $\mathrm{i}$. $\mathrm{C} 0, \mathrm{C} 1$, and $\mathrm{C} 2$ are well known Muskingum coefficients, details of which can be seen from any book of hydrology. Observed runoff record (Ro)i was used for calibrating and testing the model.

\subsubsection{Multivariate AutoRegressive Moving Average models (MARMA)}

Box and Jenkins (1976) introduced the Multivariate AutoRegressive Moving Average model (MARMA). Two models AutoRegressive (AR) and the Moving Average (MA) models have been combined in this model. This model is expressed by the following equation:

$Z_{t}=\phi_{0}+\phi_{1} Z_{t-1}+\phi_{2} Z_{t-2}+\ldots .+\theta_{1} a_{t-1}+\theta_{2} a_{t-2}+\ldots . .+a_{t}$ 
Where, $\mathrm{Zt}$ represents the predicted value, $\mathrm{Zt}-\mathrm{i}$ $s$ are the antecedent values, at-i $s$ are the residuals, and $\phi \mathrm{i} s$ and $\theta \mathrm{i}$ s are the weights allotted to each previous observation and residual, respectively. There are many forms of these models. The model after Masters (1995) has been used in this paper. Its mathematical form is given by the following equation.

$$
\begin{aligned}
& Z_{t}=\phi_{0}+\phi_{1} Z_{t-1}+\phi_{2} Z_{t-2}+\ldots+\theta_{1} a_{t-1}+\theta_{2} a_{t-2}+. .+a_{t} \\
& +\phi_{x, 1} X_{t-1}+\phi_{x, 2} X_{t-2}+\ldots+\theta_{x, 1} a_{x, t-1}+\theta_{x, 2} a_{x, t-2}+\ldots . \\
& +\phi_{y, 1} Y_{t-1}+\phi_{y, 2} Y_{t-2}+\ldots .+\theta_{y, 1} a_{y, t-1}+\theta_{y, 2} a_{y, t-2}+\ldots . .
\end{aligned}
$$

Where, $X_{t-i} s$ and $Y_{t-i} s$ are the time series observations from two different series with their residuals as $\mathrm{a}_{\mathrm{x}, \mathrm{t}-\mathrm{i}} \mathrm{s} \& \mathrm{a}_{\mathrm{y}, \mathrm{t}-\mathrm{i}} \mathrm{s}$ and $\varphi_{\mathrm{x}, \mathrm{i}} \mathrm{s}, \varphi_{\mathrm{y}, \mathrm{i}} \mathrm{s}$ and $\theta_{x, i} s, \theta_{y, i} s$ are the weights allotted to previous observations and residuals of $\mathrm{x}$ and $\mathrm{y}$ series respectively.

MARMA models are simple and easy to use. Unless the complexity of the system is highly nonlinear, their results are quite acceptable in some applications (Shamsuddin 1992). However due to their linear structure they are not always successful. Their efficiency is highly problem dependent. If the system is sufficiently nonlinear they may not perform well. In this study the model was fitted by the plots of cross correlation and partial cross correlation using the available data. The method of trial and error was adopted to find the suitable model.

\section{DATA COLLECTION}

The annual rainfall, runoff and runoff coefficient for catchment of two rivers is shown in table 1 . Seventeen years data for Khost River catchment and nineteen years data for Brandu river catchment is given in table 1. Monthly runoff data is shown in form of graphs along with the simulated values in results and discussion section. The monthly runoff data was divided in to three parts. First part was used for calibration and other two parts for validation and testing. Hundred and twenty months data was used for training of the models. For validation sets, 36 months (Oct,80 - Sep,83) and 28 months (Oct,73 Jan,76)data were used for Brandu and Khost rivers respectively. For the testing the models 72 months (Oct,83 - Sep,89) and 56 (Feb,76 - Sep,80) months data were used for Brandu and Khost rivers respectively. Data analysis is shown in table 2.

\subsection{MOdEL EFFICIENCY:}

The performances of the two models were compared with two types of statistical tests. The coefficient of efficiency (CE) and root mean square error (RMSE) (Nash and Sutcliffe 1970) as given by the equations below were chosen. In terms of (Shamseldin 1997), the models with CE values above $90 \%$ are very satisfactory, in between $80-90 \%$ are fairly good and below $80 \%$ are unsatisfactory.

\subsection{NASH-SUTCLIFFE MODEL EFFICIENCY COEFFICIENT}

The Nash-Sutcliffe model efficiency coefficient (CE) is defined as:

$C E=1-\frac{\sum_{t=1}^{n}\left(Q_{o}^{t}-Q_{m}^{t}\right)^{2}}{\sum_{t=1}^{n}\left(Q_{o}^{t}-\overline{Q_{o}}\right)^{2}}$

where $\overline{Q_{o}}$ is average of observed runoff , and $Q_{m}^{t}$ is modeled runoff. $Q_{o}^{t}$ is observed runoff at time $t . \mathrm{n}$ is total number of time steps.

Nash-Sutcliffe efficiency coefficient (CE) may be in the range of $-\infty$ to 1 . If the value of $C E$ is equal to one, it means that there is an excellent match of the simulated runoff to the observed runoff. Zero value of $C E$ represents that the simulated runoff is as accurate as the mean of the observed runoff. 
Yanbu Journal of Engineering and Science Vol. 7 (2013)

TABLE 1: ANNUAL RAINFALL, RUNOFF AND RUNOFF COEFFICIENTS FOR THE CATCHMENTS.

\begin{tabular}{|c|c|c|c|c|c|c|}
\hline \multirow{2}{*}{ Water Year* } & \multicolumn{3}{|c|}{ Brandu River } & \multicolumn{3}{|c|}{ Khost River } \\
\hline & Rainfall (mm) & Runoff (mm) & $\begin{array}{c}\text { Runoff } \\
\text { Coefficient }\end{array}$ & Rainfall (mm) & Runoff (mm) & $\begin{array}{c}\text { Runoff } \\
\text { Coefficient }\end{array}$ \\
\hline $63-64$ & - & - & - & 273.81 & 86.58 & 0.32 \\
\hline $64-65$ & - & - & - & 175.03 & 84.85 & 0.49 \\
\hline $65-66$ & - & - & - & 340.62 & 51.37 & 0.15 \\
\hline $66-67$ & - & - & - & 153.67 & 111.59 & 0.73 \\
\hline $67-68$ & - & - & - & 418.58 & 191.97 & 0.46 \\
\hline $68-69$ & - & - & - & 104.65 & 54.39 & 0.52 \\
\hline $69-70$ & - & - & - & 169.92 & 63.33 & 0.37 \\
\hline $70-71$ & 767.19 & 194.98 & 0.25 & 311.16 & 39.91 & 0.13 \\
\hline $71-72$ & 728.73 & 123.76 & 0.17 & 94.23 & 43.57 & 0.46 \\
\hline $72-73$ & 1122.17 & 346.35 & 0.31 & 330.95 & 56.97 & 0.17 \\
\hline $73-74$ & 663.45 & 125.67 & 0.19 & 308.86 & 78.52 & 0.25 \\
\hline $74-75$ & 896.11 & 161.78 & 0.18 & 258.06 & 95.69 & 0.37 \\
\hline $75-76$ & 1145.03 & 364.01 & 0.32 & 307.09 & 150.52 & 0.49 \\
\hline $76-77$ & 1184.33 & 298.14 & 0.25 & 371.61 & 133.11 & 0.36 \\
\hline $77-78$ & 1198.12 & 520.25 & 0.43 & 314.21 & 112.92 & 0.36 \\
\hline $78-79$ & 893.83 & 316.35 & 0.35 & 318.76 & 270.65 & 0.85 \\
\hline $79-80$ & 998.22 & 314.55 & 0.31 & 375.41 & 493.76 & 1.32 \\
\hline $80-81$ & 960.62 & 255.20 & 0.27 & - & - & - \\
\hline $81-82$ & 1199.90 & 280.84 & 0.23 & - & - & - \\
\hline $82-83$ & 1086.10 & 464.94 & 0.43 & - & - & - \\
\hline $83-84$ & 1106.67 & 256.39 & 0.23 & - & - & - \\
\hline $84-85$ & 1133.86 & 321.58 & 0.28 & - & - & - \\
\hline $85-86$ & 1208.79 & 371.61 & 0.31 & - & - & - \\
\hline $86-87$ & 951.33 & 354.25 & 0.37 & - & - & - \\
\hline $87-88$ & 906.46 & 264.16 & 0.29 & - & - & - \\
\hline $88-89$ & 787.80 & 178.30 & 0.23 & - & - & - \\
\hline
\end{tabular}

* Water year is calculated from Oct. to Sep. 
The value of CE less than zero occurs when the observed mean runoff is a better predictor than the simulations.

\subsection{Root MEAN SQuare ErRor}

Root Mean Square Error (RMSE) is defined as:

$$
R M S E=\left[\frac{1}{n} \sum_{t=1}^{n}\left(Q_{o}^{t}-Q_{m}^{t}\right)^{2}\right]^{0.5}
$$

where $Q_{m}^{t}$ is modeled runoff. $Q_{o}^{t}$ is observed runoff at time $t, \mathrm{n}$ is total number of values within the period of analysis.

\section{RESULTS AND DISCUSSION}

The values of the two statistical coefficients for two catchments are given in Table 2. It is observed that the conceptual model performed better than the Multivariate Autoregressive Moving Average model in training phase. In training phase the values of $\mathrm{CE}$ and RMSE for Brandu river catchment are $79.86 \%$ and $6.62 \mathrm{~mm}$ respectively for conceptual model and 34.88 and $11.91 \mathrm{~mm}$ respectively for Multivariate Autoregressive Moving Average model. The values of CE and RMSE for Khost river catchment are 74.03\% and $4.73 \mathrm{~mm}$ respectively for conceptual model and 30.30 and $7.76 \mathrm{~mm}$ respectively for Multivariate Autoregressive Moving Average model. In case of validation the values of $\mathrm{CE}$ and RMSE for Brandu river catchment are $77.79 \%$ and $6.79 \mathrm{~mm}$ respectively for conceptual model and 44.6 and $10.72 \mathrm{~mm}$ respectively for Multivariate
Autoregressive Moving Average model. In case of validation the values of CE and RMSE for Khost river catchment are $26.21 \%$ and $7.59 \mathrm{~mm}$ respectively for conceptual model and 25.66 and $7.62 \mathrm{~mm}$ respectively for Multivariate Autoregressive Moving Average model.

It is noted that in validation phase of Khost river catchment none of the two models showed very high efficiency. In test case the values of CE and RMSE for Brandu river catchment are $70.15 \%$ and $7.73 \mathrm{~mm}$ respectively for conceptual model and 43.33 and 10.65 respectively for Multivariate Autoregressive Moving Average model. In this phase the Multivariate Autoregressive Moving Average model did show the good performance. In test case the values of CE and RMSE for Khost river catchment are $73.11 \%$ and $7.64 \mathrm{~mm}$ respectively for conceptual model and 37 and 14.7 respectively for Multivariate Autoregressive Moving Average model. The performance of Multivariate Autoregressive Moving Average model for Khost river catchment also is not acceptable.

Looking at the results and the catchment details given above it may be expected that the $\mathrm{R}-\mathrm{R}$ processes of these rivers are nonlinear due to which the MARMA models might not be able to catch this nonlinear functional relationship. Another reason for this may be the high percentage of noise and errors contained in the dataset that MARMA models failed to simulate the R-R processes.

TABLE 2: COMPARATIVE PERFORMANCES OF CONCEPTUAL AND MARMA MODELS FOR TWO WATERSHEDS

\begin{tabular}{|c|c|c|c|c|c|c|c|}
\hline \multirow{2}{*}{$\begin{array}{l}\text { Model } \\
\text { Name }\end{array}$} & \multirow[b]{2}{*}{ Watershed } & \multicolumn{2}{|c|}{ Training set } & \multicolumn{2}{|c|}{ Validation set } & \multicolumn{2}{|c|}{ Test set } \\
\hline & & $\begin{array}{l}\mathrm{CE} \\
(\%)\end{array}$ & $\begin{array}{l}\text { RMSE } \\
(\mathrm{mm})\end{array}$ & $\begin{array}{l}\text { CE } \\
(\%)\end{array}$ & $\begin{array}{l}\text { RMSE } \\
(\mathrm{mm})\end{array}$ & $\begin{array}{l}\text { CE } \\
(\%)\end{array}$ & $\begin{array}{l}\text { RMSE } \\
(\mathrm{mm})\end{array}$ \\
\hline Conceptual & Prond o. & 79.86 & 6.62 & 77.79 & 6.79 & 70.15 & 7.73 \\
\hline MARMA & Brandu river & 34.88 & 11.91 & 44.60 & 10.72 & 43.33 & 10.65 \\
\hline Conceptual & Khost & 74.03 & 4.73 & 26.21 & 7.59 & 73.11 & 7.64 \\
\hline MARMA & River & 30.13 & 7.76 & 25.66 & 7.62 & 37.00 & 14.70 \\
\hline
\end{tabular}


The time series were not investigated for longterm and seasonality trends and were not removed from the data. The graphical comparisons of the models for the two watersheds are shown in Fig 2, 3 and 4. The results of all the three phases have been shown i.e. training, validation and test phases. The results of these figures confirm the above discussion given on the basis of statistical tests.

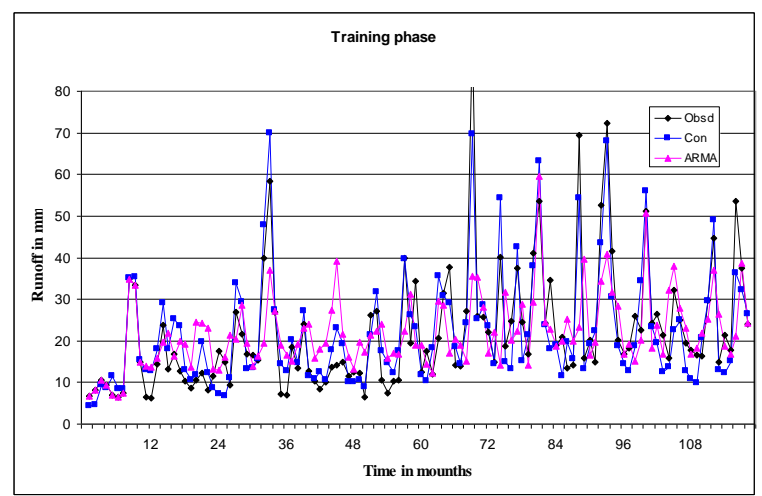

Fig.2. Comparison of results of models in Training phase for Brandu River catchement (Data of 120 months (1970 - 80))

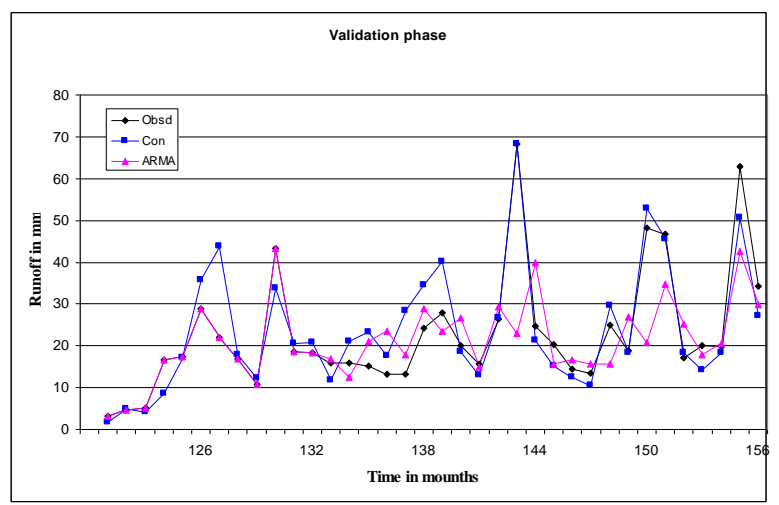

Fig.3. Comparison of results of models in validation phase for Brandu River catchement (Data of 36 months (Oct,80 - Sep,83))

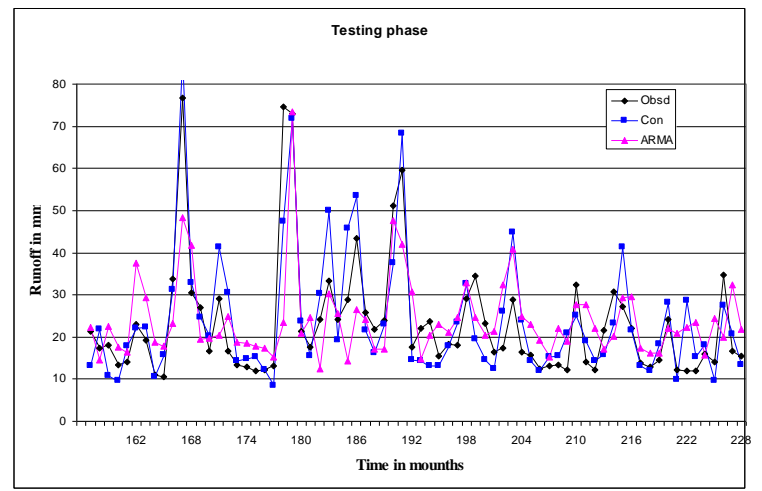

Fig.4. Comparison of results of models in testing phase for Brandu River catchement (Data of 72 months (Oct,83 - Sep, 89))

\section{CONCLUSION}

Mathematical conceptual model and Multivariate Autoregressive Moving Average model have been developed and applied to two catchments in Pakistan namely Brandu and Khost Rivers catchments, for conditions when the collected hydrological data was short and was presumed to contain high percentage of error and noise. Monthly runoff from monthly rainfall has been forecasted. It is concluded that mathematical conceptual model provided comparatively better monthly forecasts especially during the training phase. The performance of Multivariate Autoregressive Moving Average model is not up to the mark. In validation phase of Khost river catchment none of the two models showed very high efficiency. Overall performance of mathematical conceptual model is acceptable and it can applied for forecasting the monthly runoff with reasonable level of confidence.

\section{REFERENCES}

[1] Abulohom M.S., Shah S.M.S., and Ghumman A.R., "Development of a rainfall-runoff model, its calibration and validation", Journal of Water Resources Management, 15, pp. 149-163, 2001

[2] Bahremand A. and Smedt F. De, "Distributed Hydrological Modeling and Sensitivity Analysis in Torysa Watershed, Slovakia", Water Resources Management Volume 22, Number 3, 393-408, 2010

[3] Bhadra A., Bandyopadhyay A., Singh R., Raghuwanshi N. S., "Rainfall-Runoff Modeling: Comparison of Two Approaches with Different Data Requirements", Journal of Water Resource Management No 24, pp37-62, 2010

[4] Boughton, W., and Chiew F., Estimating runoff in ungauged catchments from rainfall, PET and the AWBM model: Environmental Modelling \& Software, v. 22, p. 476-487, 2007

[5] Box, G.E., and Jenkins, G.M., "Time series Analysis: Forecasting and Control", Prentice Hall, San Francisco, California. 1976 
[6] Masood M., Ghumman A.R., " Estimation of a unique Pair of Nash Model Parametrs: An Optimization Approach" Journal of water resources management, DOI-1007/s11269, 2010

[7] Masters, T. : Neural, novel \& hybrid algorithms for time series prediction. John Wiley \& Sons, Inc., USA, 1995

[8] Perrin, C., C. Michel, and Andréassian V., Improvement of a parsimonious model for stream flow simulation: Journal of Hydrology, v. 279, p. 275-289, 2003

[9] Ponce, V.M., Engineering Hydrology, "Catchment Routing" pp. 306-331, 1989

[10] Shamseldin, A.Y., "Application of a neural network technique to rainfall-runoff modeling", Journal of Hydrology, 199, 272-294, 1997

[11] Shamsuddin M. N.: A Short Note on Forecasting Natural Rubber Prices Using A MARMA. The Malaysian Journal of Agricultural Economic, 9, pp. 59-68, 1992

[12] Soil Survey of Pakistan Department : Reconnaissance soil survey', Soil survey of Pakistan, 1975

[13] Tingsanchali, T., and Gautam, M.R., "Application of Tank, NAM, ARMA and neural network models to flood forecasting", Hydrological Processes, 14, 2473-2487, 2000

[14] Vandewiele, G.L., Xu, C-Y., and Win, N-L., "Methodology and comparative study of monthly water balance models in Belgium, China and Burma", Journal of Hydrology, 134, pp. 315-347, 1992 


\title{
نمذجة سيول الأمطار لمستجمعات المياه محدودية المعلومات
}

\author{
عبد الرزاق جهمان1، يسري غزاو²، محمد ابولهوم1 \\ 1

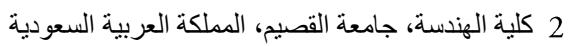 \\ إعارة من: كلية الهندسة، جامعة الاسكندرية، مصر الصنة العربة
}

(الملخص:

الجريان الشهري من تجمعات مياة الأمطار مطلوب لأدارة و هندسة الموارد المائية. تتناول هذه الورقة نمذجة الجريان السطحي من مستجمعات المياه التي لديها بيانات من نوعية متدنية. نموذجين هما النموزج الرياضي المفاهيمي والنموذج متعدد المتغير ات ذو الانحدار الذاتي تم تطوير هما وتطبيقهما على اثثين من مستجمعات المياه (نهر براندو و نهر خوست) في الباكستان. معدل هطول الأمطار والأرصاد الجوية التى استخدمت تم جمعها من ادارة الأرصاد الجوية فى مقاطعة بلوشنتان والمقاطعة الحدودية الثمالية الغربية، باكستان. نتائج النموذج الرياضي المفاهيمي و النموذج متعدد المتغيرات ذو الانحدار الذاتي تمت مقارنتهما مع بعضهما البعض. لوحظ أن نتائج النموذج متعدد المتغيرات ذوالانحدار الذاتي غير مرضية بسبب عدم الأستقامة العالية في سقوط الأمطار و السيول من هذه المستجمعات. أداء النموذج المفاهيمي كانت مقبولة. 